\title{
Female Experience and Language in Monta Kroma's poetry
}

\author{
ANNA AUZIN,A
}

\begin{abstract}
Monta Kroma (1919-94) is one of the key female representatives of Latvian poetry in the $1960 \mathrm{~s}-80 \mathrm{~s}$. She is one of the most uncommon Latvian poets of this time as well - a brilliant modernist, whose poetics are different from the mainstream in both subject and form. Kroma started writing in the 1940s composing stanzas of socialist realism. From the 1960 s onward, after completing her studies in Moscow, she mostly writes in vers libre, revealing the inner worlds of women living in the city, which, in the context of the Soviet ideology, makes her poetry unique and not always officially sanctioned.

The focus of the paper is the poetics of Monta Kroma from the viewpoint of feminist theories. The main purpose is to explore the feminine features of her poetics, analysing the female subject and writing in accordance with gynocriticism and post-structuralist French feminism, paying attention to the language and means of expression.

Though a feminine or masculine way of writing exists apart from the author's gender, Kroma's poetry can be viewed in the light of a specifically female language, an alternative to patriarchal discourse. Such a way of writing - the so-called écriture féminine is emphasised as a concept and also demonstrated in the works of poststructuralist feminists Hélène Cixous and Luce Irigaray. As écriture féminine is deeply related with the body and sexuality, Kroma's sensuous poetics with its semiotic elements presents a fruitful field of research in the context of these ideas.
\end{abstract}

Keywords: poetry, feminist theories, feminine writing, feminine language, soviet times

This article is devoted to Monta Kroma's poetry, analysing both the subject themes and the means of expression from the viewpoint of Feminist Theory. Kroma is one of the key female representatives of Latvian poetry in second half of $20^{\text {th }}$ century. I argue that Kroma's poetry portrays the female experience in a specifically feminine way that breaks traditions and norms in terms of both images and form. During the Soviet regime her poetics deviate from the mainstream, which is still expressly patriarchal. While I agree with the statement that a feminine or masculine way of writing exists apart from an author's gender, 
Kroma's poetry can be viewed in the light of a specifically feminine language, an alternative to patriarchal discourse, which makes her one of the most uncommon Latvian poets of her time.

We can wonder if it is still suitable nowadays to search for specific feminine features in texts written by female authors. In 2008, feminist literary critic Toril Moi wrote that the question of the woman writer, a popular topic during the decade from the mid-1970s to the mid-1980s, disappeared from the feminist theoretical agenda around 1990 (Moi 2008: 259-263). She speaks of an „intellectual schizophrenia, in which one half of the brain continues to read women writers while the other continues to think that the author is dead, and that the very word 'woman' is theoretically dodgy" (Moi 2008: 264). Referring to the ideas of deconstruction, especially the one that the text, once it is written, lives its own life and the author does not matter anymore, Moi affirms, that „[u]sually, the writer begins by assuring us that she really does not have anything against Barthes or Foucault; or that she is not really writing about real, living authors, but only about the figure of the author in the literary text" (Moi 2008: 264). Though, Moi draws attention to the brilliant literary critics who were still working on women writers during the first decade of this century, since the need to reconsider the question of the female subject still exists. Even when it is possible to view a literary text as just a text, without any reference to a speaking subject, I say it is personality that makes each text unique. And as Moi notes: "[I] f a woman's vision of the world is strongly marked by her gender, that is as potentially interesting as the absence of a gendered view [...]" (Moi 2008:268).

Insofar as we speak about the ways in which women's experience is portrayed in literature, there is not much disagreement among the different theorists. Often, especially in the Anglo-American tradition, women's writing has been defined as writing by women, about women, for women. However, if we address language and style of writing, the question becomes much more complicated. There is no unambiguous answer to the question of what exactly can be understood by such terms as female or male, feminine or masculine images or structures of language, and to what degree they can be linked with the gender of the literary subject. A classic presumption is that writing should be individual and sexless rather than sex-determined. Some hold the view that the difference between masculine and feminine writing can be found in metaphors, that women use certain images more often than men (Moers 1996: 293-294). Others, like Mary Ellmann, speak about the masculine voice, which Ellmann characterises in terms of authority (Ellmann 1996: 295-297). It can be used by both male and female subjects. For instance, Ellmann discovers this masculine tone in otherwise feministic writing by Simone de Beauvoir (Ellmann 1996: 295-297). 
AUZIN̦A

In general, the Anglo-american literary tradition is considered to be descriptive. A parallel development took place in French feminism, which was closer to a psychoanalytic conception of femininity. Though one of its key female representatives, Julia Kristeva, used to be cautious about any contention that a specifically feminine writing exists (Kristeva 1996: 301-303), the concept of écriture féminine, the feminine writing, presented by her colleagues Hélène Cixous and Luce Irigaray, promoted writing marked by femininity. In general the term écriture féminine meant writing by women, although it was acknowledged that feminine writing could occasionally be found in texts written by men, too.

In my analysis of Kroma's poetry I draw mainly on Julia Kristeva's ideas, which are based on French psychoanalyst Jacques Lacan's concepts of the mirror and pre-mirror stages. Kristeva distinguishes between the symbolic and presymbolic or, as she calls it, semiotic realms of language (Kristeva 1984). For Kristeva "semiotic" is something distinct from the discipline of semiotics - a psychosomatic modality of the signifying process, the inner drives, and their articulations. In other words, semiotic is something beyond words, beyond literal meaning, the source of biological drives, rhythm and sound, which can only exist in relationship with and through the "symbolic," through the structure of language that attributes meaning to things. Kristeva associates the symbolic with masculine code and the semiotic with feminine code. While Cixous and Irigaray call for building an understanding of the feminine symbolic, Kristeva considers that it is impossible to divide masculine from feminine or symbolic from semiotic. "These two modalities [the semiotic and symbolic] are inseparable within the signifying process that constitutes language, and the dialectic between them determines the type of discourse (narrative, metalanguage, theory, poetry, etc.) involved; in other words, so-called 'natural' language allows for different modes of articulation of the semiotic and the symbolic. [...] Because the subject is always both semiotic and symbolic, no signifying system that the subject produces can be either 'exclusively' semiotic or 'exclusively' symbolic, and is instead necessarily marked by an indebtedness to both." (Kristeva 1984: 24). The semiotic is repressed by the symbolic, but it also "breaks" through and disrupts the symbolic in art, music, and poetry. " $[\mathrm{T}]$ he symbolic - and therefore syntax and all linguistic categories - is a social effect of the relation to the other, established through the objective constraints of biological (including sexual) differences and concrete, historical family structures. Genetic programming is necessarily semiotic: it includes fundamental processes such as displacement and condensation, absorption and repulsion, rejection and stasis, all of which function as innate preconditions, "memorisable" by the species, for language acquisition." (Ibid. 29) 
So, according to Kristeva, we can find feminine elements as they appear in poetic texts (including those which are written by male authors) as deviations from norms.

Now let's go back to Monta Kroma, the main hero of this article. Kroma provides us with a very rare example of when a poet has written her or his best works after the age of forty, when most poets gradually stop writing well. Born in 1919 in a working class family and raised by her communist stepmother, Kroma starts writing in the 1940s with the composition of stanzas depicting socialist realist themes. Her first book Svinigais solijums (The Solemn Promise, 1947) is for children, the main subject being the lives of Young Pioneers. The collection is full of poems like "Meitene ar sarkano kaklautu” („The Girl with the Red Kerchief") or "Uz pionieru pili" ("To the Young Pioneer's Palace.") The next book is called Tev, gvard! (For You, Guardsman, 1950). It consists of five parts the first speaks of the second world war and is based on her real life experience working as medical assistant during that time; the second is about building a new life after the war; the third is about life in the kolhoz, the fourth is devoted to love and friendship, and the fifth is about the 'path to communism'. While the first book is written in trochee, the second is mostly in iambus. Kroma's next book, Tālo apvāršnnu zemè (In the Land of Distant Horizons, 1959), is a long epic poem based on her experiences during the Virgin Lands Campaign in the late 1950s. It can be called polymetrical with a tendency toward vers libre.

In 1960 Monta Kroma leaves for Moscow to study in the Advanced Literary Courses at the Maxim Gorky Literature Institute. Among other writers and ideas she becomes acquainted with works of Voznesensky, who, together with Walt Whitman, Nazim Hikmet, and Latvian poet Ojārs Vacietis, was a poet who greatly influenced Kromas further poetry. Kroma's fourth book Tuvplānā (Closeup, 1966) is a kind of watershed in her creative work. She no longer focuses on social themes. Now the individual emotions of the speaking subject are brought into the foreground. Here we can see her gradually transition into vers libre, the free verse, with some poems written in pure vers libre. Here Kroma frees herself from regular rhyme patterns. With her next collection of poetry Lüpas. Tu. Lüpas. Es. (Lips. You. Lips. Me., 1970) - Monta Kroma transforms into a brilliant modernist, revealing the female inner world in the city. She is now writing mostly in vers libre, using the method of the stream-of-consciousness and peculiar graphic layouts for her texts. Though followed by seven other books, Lüpas. Tu. Lüpas. Es. was and is considered by many, including herself, to be Kroma's best collection.

The female experience in this collection, as mentioned before, is individual. The speaking subject does not fit neatly into social roles. She is no longer a Young Pioneer, a war nurse, or a factory worker and, importantly, she is not a 
AUZIN,A

mother - the obligatory and most important social role for a woman. The subject is simply a human being with a body. The heroine of Kroma's poetry dares to speak about her own inner feelings - often bodily and sensual. If she talks about romantic love, she is not an object there - she speaks from the position of being inside love. Kroma's sensuous poetics, along with its units of rhythm, presents a fertile field of research in the context of the ideas of French feminism.

Let us see what it looks like:

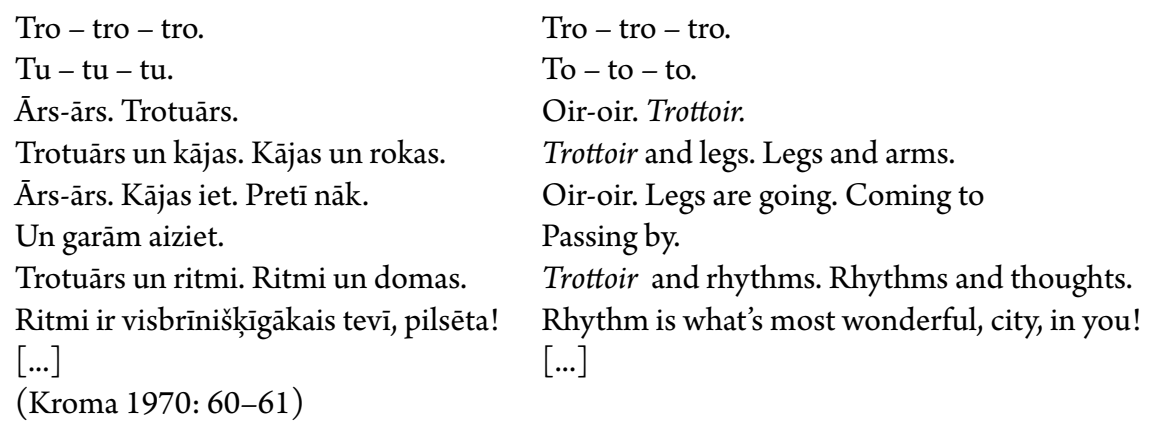

As I consider this poem to be very important, yet impossible to translate, in this case I need to present the text in English translation side by side with the Latvian original to show all the connotations of the divided words. As we see, the word trottoir is divided in syllables and each of them repeats, building a rhythm similar to what one hears while walking down the street. Besides, while trotuārs in Latvian means pavement, the syllable tu separately means you; and ārs means outside, outdoors. I used the French word trottoir instead of the English pavement to demonstrate Kroma's phonetics but even so, some of the meanings of the syllables are lost. A rhythm created by dividing words in syllables makes us imagine the heroine walking on the asphalt as if we were hearing this poem in the sound of her steps. The speaking subject of the poem is aware of that as she mentions rhythms. Thus this poem demonstrates how the semiotic realm of language enters into the symbolic.

The next poem also uses an irregular rhythm. Since Latvian syntax is flexible, the texts are sufficiently correct grammatically, so we can leave that aspect aside and speak about the bodily pleasure of rhythm rather than the strain between rhythm and syntax as between semiotic and symbolic (which Kristeva mentions when analysing French texts, referring to the statement of Mallarme that syntax prevents the poet from following the inner rhythm). Bodily pleasure created through rhythm is stressed at the semantic level of the text as well: 
Female Experience and Language in Monta Kroma's poetry

I have changed, the whole of me, right from the tips of my hair

$$
\begin{aligned}
& \text { to my toes } \\
& \text { I am wholly averse } \\
& \text { to listening } \\
& \text { to beautiful tunes } \\
& \text { and to waltzes. }
\end{aligned}
$$

They make me feel sad.

And then I am stricken with dread that your coat at the dry cleaner's might with complete unconcern be tossed in a heap with the others.

Then I develop a longing for things that eluded my grasp.

Then it strikes me it might be already too late to start bearing four children.

And then I'm exceedingly sad.

But my time-table does not allow for anyone sad - such a person, the same as sufferer from flu, serves no purpose whatever.

I have changed, I am keen now on jazz and on rhythm, the whole of me, right from the tips of my hair to my toes I am keen now on rhythm.

In my head there's my inner jazz.

It makes me feel good.

Then my thinking is quick of the mark.

For, always, there are situations arising which ask for immediate and preferably apt responses.

Than it's like dancing away all my working day hours. And this lightness is now the style we employ in our work. 
AUZIN,A

Then it's no problem to walk after work through the food stores and shops selling trifles, and generally dart here and there. $[\ldots]$

(Kroma 1970:68-70) ${ }^{1}$

The images here are based in contrasts:

beautiful tunes and waltzes

feel sad

with dread that your coat at the dry cleaner's might with complete unconcern

sad person serves no purpose whatever this lightness is now the style we employ in our work;

it's like dancing away all my working day hours

a longing for things that eluded my grasp (the past) on jazz and on rhythm, inner jazz

feel good no problem to walk after work through the food stores and shops selling trifles situations which ask for immediate responses (the present)

Here we see a contrast between "beautiful tunes and waltzes" and "jazz and rhythm". The voice of the poem's subject tells us that beautiful tunes make her feel sad. They remind her it might be already too late to start bearing four children, or, in other words, she does not fit in with social norms. In contrast, "inner jazz" makes her feel good - this suggests that she lives in harmony with her inner self when she lives in this particular moment. This poem has its own inner rhythm, which is accentuated by the graphic layout. The rhythm is irregular and reminds us of the pulsing drives Julia Kristeva speaks about.

Translated by Ruth Spears (see Poetry from Latvia II. Kalnajs, A. (ed.), 1982. As the graphic layout of this and next poem in this translation is slightly different, I used it here as it is in original to show indentions more precisely. 
Female Experience and Language in Monta Kroma's poetry

In the next example uses a different approach. The individual, inner feelings of the subject of the poem are contrasted with official, formal, outer displays that Kroma compares to roses without scent:

- "No", - I told her, that saleswoman there at the florist's. (I don't even know what she looked like, such lack of expression.)

- "No", - I told her, - to me they're no use, they're not scented.

(She lightly picked up the sixth one,

all of them scarlet, picked up the seventh and, clasped in her hands, the roses of course made a show.)

- "No", - I told her, - such roses are put on a table for top-rank officials. It's just for myself that I need them. She'd surely at last understand that to me they were useless, and put them all back on the counter.)

[...

- "No", - I told her, - by morning, they have to be wilted, it would be improper if roses were still to be fresh in the morning, it would be quite monstrous. (At last she put them all back on the counter. What kind of saleswoman was she, dealing with flowers, bet never, an inkling that roses are fresh in the morning it looks as if nothing at all had happened during the night. What kind of saleswoman was she, dealing with flowers, that's why I forget what she looked like, such lack of expression.)

(Kroma 1975:45)²

2 Translated by Ruth Spears (see Poetry from Latvia II. Kalnajs, A.,ed., 1982). 
AUZIN,A

This text is organised into irregular parts with frequently broken lines, six times starting with words - "No", I told her. This seemingly innocent text is possible to read as politically rebellious, especially in such phrases as "such roses are put on a table for top-rank officials", suggesting the distance the subject feels between herself and the Communist Party. The other possible translation is presidium. Large parts of text are put in parenthesis as if these words are not said out loud, just thought in secret.

The next poem is also based on contrast:

The doors remains open.

And stairs leading down and the street in which you are going away

Enter my home

Blue stairway.

Blue street.

Blue is the colour of all on which you withdraw, -

Blue as is distance.

Through the walls, I can see you going away,

Quite recently, though, my walls were opaque

As I waited for you to be coming.

I rested my hands on them, and I rejoiced

To find myself here in this nest.

Not that I saw, but I knew

You were coming, here, up the street, up the stairs.

Yellow street.

Yellow stairs.

Yellow - the colour of all in which you draw near, -

Yellow like closeness.

When walls are transparent, this isn't a nest any more.

My sight is a keen as an eagle's,

I see you are going away in the five hundredth street.

The street, the five hundredth, blue as a distance,

Enters my home.

The door remains open.

$(\text { Kroma 1970: 35) })^{3}$

3 Translated by Ruth Spears (ibid.) 
Opposites here are used in pairs: blue/yellow; distance/closeness. The colour blue is linked with a sense of distance; yellow is linked with closeness. Although in the culture colours often have symbolic meaning, in Julia Kristeva's opinion, colours may be used as units that structure vocal and kinetic rhythms. "Checked by the constraints of biological and social structures, the drive charge thus undergoes stases. Drive facilitation, temporarily arrested, marks discontinuities in what may be called the various material supports [matériaux] susceptible to semiotisation: voice, gesture, colours. Phonic (later phonemic), kinetic, or chromatic units and differences are the marks of these stases in the drives. Connections or functions are thereby established between these discrete marks which are based on drives and articulated according to their resemblance or opposition, either by slippage or by condensation. Here we find the principles of metonymy and metaphor indissociable from the drive economy underlying them" (Kristeva 1984: 28). In Kroma's poem images of colours are used to demonstrate visual connotations. Here blue represents distance, so we can say the author borrows the meaning of the colour blue from the visual arts. As blue is a cold colour and yellow is a warm colour, they can be used to show a colour perspective. Here I have to note that in Latvian blue does not have a meaning of sadness as it does in English, and all the emotions suggested by these colours are rather associative and subjective. Though sometimes warm colours - such as yellow and orange are considered to be more joyful than the cold colours - such as blue and violet. So, since the colours in this poem can still be associated with a kind of symbolic meaning, but the meaning derives from sensual perception. The next poem is a better example of colours used as units of rhythm in Kroma's poetry:

\author{
Yellow. Violet. Green. Blue. \\ Yellow. Violet. Green. Blue. \\ You are violet. I am blue. \\ You are blue. I am violet.
}

$(\text { Kroma 1970:16) })^{4}$

Here we can better see that the use of colours is not symbolic, that it is rather the changing rhythm of the sounds of the names of those colours.

As we see from these examples, Monta Kroma's method of writing is deeply intertwined with the body and sexuality. I would like to note that most of these texts are written in 1960s, some years before the concept of écriture féminine appeared. In their book, La jeune née, 1975 (Newly Born Woman, Hélène Cixous and Catherine Clément show something in the feminine that is foreign

\footnotetext{
$4 \quad$ Translated by me (A.A.)
} 
AUZIN,A

and incomprehensible to those outside of it, and they say that this lack of understanding is what makes women social transgressors. While they do it through essay, calling on women to write, Monta Kroma in Soviet Latvia put this concept in practice, just feeling free to write. As Toril Moi notes, "Every writer will have to find her own voice, and her own vision. Inevitably, a woman writer writes as a woman, not as a generic woman, but as the (highly specific and idiosyncratic) woman she is." (Moi 2008:268)

\author{
Anna Auziņa \\ annaauzin@gmail.com \\ Linnu iela 16 \\ Carnikava \\ LV-2163 Carnikavas novads \\ LATVIJA
}

\title{
Bibliography
}

Cixous, H., Clement, C. 1987 [1975]. The Newly Born Woman. Oxford, MN: University of Minnesota Press.

Ellmann, M. 1996 [1986]. Thinking About Women. - M. Eagleton, ed., Feminist Literary Theory: A Reader. Blackwell: 295-297.

Irigaray, L. 1993 [1987]. Sexes and Genealogies. New York: Columbia University Press.

Kristeva, J. 1996 [1977]. Talking about Polylogue.- M. Eagleton, ed., Feminist Literary Theory: A Reader. Blackwell, 301-303.

Kristeva, J. 1984 [1974]. Revolution in Poetic Language. New York: Columbia University Press.

Kroma, M. 1947. Svinīgais solījums: Piektās klases skolnieka stāsts. Rīga: Latvijas Valsts izdevniecība.

Kroma, M. 1950. Tev, gvard! Riga: Latvijas Valsts izdevniecỉba.

Kroma, M. 1957. Tãlo apvāršņu zem: Jaunības dziesma. Rīga: Latvijas Valsts izdevniecība.

Kroma, M. 1970. Lüpas. Tu. Lūpas. Es. Rīga: Liesma.

Kroma, M. 1975. Skaņas nospiedums. Rīga: Liesma.

Moers, E. 1996 [1978]. Literary Women. - M. Eagleton, ed., Feminist Literary Theory: A Reader. Blackwell: 1996 [1986], 293-294.

Moi, T. 2008. I am not a woman writer. - Feminist Theory, An International Interdisciplinary Journal, 9 (3), 259-271. 